\title{
Occurrence and Yield Effects of Wheat Infected with Triticum mosaic virus in Kansas
}

Dallas L. Seifers and T. J. Martin, Kansas State University, Agricultural Research Center-Hays, Hays 67601-9228; and John P. Fellers, United States Department of Agriculture-Agricultural Research Service HWWGRU, Department of Plant Pathology, Manhat$\tan , \mathrm{KS} 66506$

\begin{abstract}
Seifers, D. L., Martin, T. J., and Fellers, J. P. 2011. Occurrence and yield effects of wheat infected with Triticum mosaic virus in Kansas. Plant Dis. 95:183-188

Triticum mosaic virus (TriMV) infects wheat (Triticum aestivum) in the Great Plains region of the United States. This study determined the occurrence of TriMV at three locations over 3 years and yield effects of wheat mechanically infected with TriMV. Wheat infection with TriMV, Wheat streak mosaic virus (WSMV), and the High Plains virus (HPV) was verified using enzyme-linked immunosorbent assay. Both wheat singly infected with TriMV and doubly infected with TriMV and WSMV occurred at three, two, and one locations in 2007, 2008, and 2009 , respectively. Wheat singly infected with HPV occurred at one and two locations in 2008 and 2009, respectively. Wheat doubly in-

fected with WSMV and HPV occurred at one location in 2008 and 2009. Infection with TriMV declined at two locations each year and, at the third location, it increased the second year and was not detected the third year. WSMV infection increased, except for a decline the third year at one location. In contrast to $3.0 \%$ infection of wheat with TriMV and WSMV at one location, $85 \%$ of the wheat $1.6 \mathrm{~km}$ from that site was infected with TriMV and WSMV in 2009. Infection of wheat with TriMV caused significant yield and volume weight reductions in Danby, RonL, and Jagalene but not KS96HW10-3 wheat.
\end{abstract}

Triticum mosaic virus (TriMV) was first identified infecting wheat (Triticum aestivum L.) in Kansas in 2006 (12). TriMV has since been identified from infected wheat in the Great Plains in Colorado, Nebraska, Oklahoma, South Dakota, Texas, and Wyoming (1), and in Montana and North Dakota in 2009 (2). The virus is mechanically transmissible, associated with a $35-\mathrm{kDa}$ coat protein when analyzed by sodium dodecyl sulfate polyacrylamide gel electrophoresis (SDS-PAGE), and antiserum raised to the coat protein preferentially reacted only to TriMV in enzyme-linked immunosorbent assay (ELISA) and Western blot assay (12). Symptomatic plants were shown to be associated with flexuous rods that ranged in length from 550 to $990 \mathrm{~nm}$, with a modal length of $800 \mathrm{~nm}$ when analyzed by electron microscopy (12).

The sequence of the coat protein TriMV was determined by time-of-flight mass spectroscopy and from DNA sequence of cloned, reverse-transcribed viral RNA. Analysis showed that TriMV was distantly related to Sugarcane streak mosaic virus (12). The nucleotide sequences have been determined for the entire genome of the Kansas 06-123 isolate (3) and a Nebraska isolate (20) of TriMV, and they are $99.8 \%$ identical.

Wheat curl mites (WCM), Aceria tosichella Keifer, were observed on plants originally infected with TriMV (12). Subsequent studies using WCM demonstrated that the WCM could transmit TriMV both singly and in combination with Wheat streak mosaic virus (WSMV) (11). Thus, in addition to TriMV, the WCM also transmits WSMV (18) and the High Plains virus (HPV) (9).

Corresponding author: D. L. Seifers, E-mail: dseifers@ksu.edu

Contribution No. 10-288-J from the Kansas Agricultural Experiment Station.

Research in Kansas was partially funded by a grant from the Kansas Wheat Commission.

Accepted for publication 4 October 2010.

doi:10.1094/PDIS-03-10-0222

(C) 2011 The American Phytopathological Society
Previously, only naturally infected wheat and barley have been confirmed as hosts of TriMV (12). But, since then, the reaction of row crop species to infection by TriMV and WSMV and the identification of differential hosts for these viruses has been conducted (10) and, in another study, the reaction of row crop species to infection with TriMV and WSMV was investigated and differential hosts were also identified (19).

In 2006, wheat plants infected with TriMV were not geographically localized but were identified in several different locations in Kansas (12). The few wheat lines sampled were either singly infected with TriMV or infected with both TriMV and WSMV. We desired to determine the affect of infection with TriMV on yield of selected wheat cultivars in replicated field experiments and to further determine the occurrence of TriMV infection at different locations in Kansas. We report occurrence of TriMV infection of wheat at different locations over a 3-year period and yield responses of wheat infected with TriMV.

\section{Materials and Methods}

Source and maintenance of the 06-123 isolate of TriMV. The 06-123 isolate of TriMV was isolated from KS06HW79 wheat in 2006 at the Kansas Agricultural Research Center-Hays (KSU$\mathrm{ARCH}$ ), at Hays, KS (12). The virus was propagated in 'Tomahawk' wheat by mechanical inoculation as described previously (12). Following inoculation, the plants were held in a greenhouse under natural lighting.

Antiserum sources. The TriMV antiserum was used as a whole serum at a 1:4,000 ( $\mathrm{vol} / \mathrm{vol})$ dilution prepared from a stock solution of $1 \mathrm{mg}$ protein/ml and was raised as described previously (12). The WSMV antiserum (1:1,000 vol/vol) (7), and antiserum to the HPV (HPV-WO; 1:1,000 vol/vol) (5) dilutions were made from stocks adjusted to $1 \mathrm{mg}$ protein/ml. The name Wheat mosaic virus has been suggested to replace HPV (17); however, for the purpose of continuity with the literature, the name HPV is used. Positive controls consisted of the 06-123 isolate of TriMV (12), the Sidney 81 isolate of WSMV (12), and the 06-Maize A isolate of HPV (16).

Indirect ELISA. The procedure used was described previously (12). Antibody dilutions were described above. The goat anti-rabbit antibody or alkaline phosphatase conjugate was used at 1:3,000 (vol/vol) (Southern Biotechnology Associates, Birmingham, AL). 
Absorbance was measured at $405 \mathrm{~nm}$ using a Titertek Multiscan plate reader (Flow Laboratories, Inc., McLean, VA) and values were arbitrarily considered positive if twice those of the equivalent mock-inoculated control.

Infectivity assays. Tomahawk wheat was inoculated mechanically (finger rub) when at the single-leaf stage with 1:10 (wt/vol) extracts prepared from appropriate infected wheat sources (as described above). Following inoculation, the plants were held in a greenhouse under natural lighting and symptom ratings were done at 14 to 21 days post inoculation (DPI).

Planting and sampling of wheat in the Kansas intrastate wheat nurseries. Wheat was planted in six-row plots, with $3.0-\mathrm{m}$ long rows with a $0.3-\mathrm{m}$ row spacing, and seeded at $50 \mathrm{~kg} / \mathrm{ha}$, with each wheat source being planted in four replications in a randomized complete block design. The Ellis, Graham, and Ness County Kansas intrastate wheat nurseries (KINs) were planted 30 September, 10 October, and 13 October 2006, respectively; 25 September, 28 September, and 29 September 2007, respectively; and 27 September, 26 September, and 29 September 2008, respectively. The location of the nurseries varied within each County during the 3 years.

Wheat samples were taken from the Ellis, Graham, and Ness County KIN locations in 2007, 2008, and 2009. A symptomatic leaf was taken from each symptomatic plant in the outer two rows only of each plot of the cultivars or lines Danby, RonL, Everest, KS970274-14-9, KS96HW10-3 in 2007; Danby, Hatcher, KS03HW12-6, Everest, KS05HW15-2, and KS96HW10-3 in 2008; and Danby, Hatcher, Everest, RonL, and KS96HW10-3 in 2009 from Ellis, Graham, and Ness KIN locations. The inner rows of each plot were not sampled because they were used for yield analyses. The leaf samples were placed in self-sealing plastic bags and the bags placed in a cooler on ice and taken to the laboratory. Samples were processed and analyzed by ELISA as described above. Wheat lines sampled with temperature-sensitive resistance to WSMV were KS96HW10-3 (13), KS03HW-12 (14), and RonL (15).

Alternate Ness County wheat sampling site. During 2009, wheat plants growing in a field $1.6 \mathrm{~km}$ from the Ness KIN location (planted at an unknown time with a mixture of the wheat cvs. TAM 112 and T 136) were sampled for ELISA. Wheat was sampled on 4 May, the same day as the sample taken at the Ness KIN location $1.6 \mathrm{~km}$ away, by randomly selecting 40 symptomatic plants, and a piece of leaf tissue was harvested separately from each plant and processed for analyses by ELISA.

Analysis of WSMV isolates isolated from temperature-sensitive wheat lines growing in the field. In 2009, five WSMV isolates were obtained from symptomatic wheat plants with temperature-sensitive resistance to WSMV that were growing in the field at the Ness County KIN. Four of the isolates were from four symptomatic KS96HW10-3 plants and one from a symptomatic RonL wheat plant. Extracts prepared from the symptomatic plants all reacted to WSMV antibodies in ELISA (data not shown). The isolates were transferred to Tomahawk wheat at the two-leaf stage by mechanical inoculation with 1:10 (wt/vol) extracts prepared from the source plants.

To test each isolate for its ability to systemically infect the different wheat lines with temperature-sensitive resistance to WSMV or to a susceptible wheat source, 10 seeds each of KS96HW10-3, KS03HW12, RonL, and the susceptible Tomahawk wheat control were planted into a large, metal (21-by-31-cm), soil-filled (fine montmorillonitic, mesic Typic Argiustoll) flat having 20 rows, so that a row of each of these wheat entries would be inoculated with each WSMV isolate. The flat was held in a greenhouse under natural lighting until the plants were at the single-leaf stage (temperature ranged from 21 to $30^{\circ} \mathrm{C}$ ). Plants of each of the lines were then mechanically inoculated with a $1: 10$ (wt/vol) dilution of extract prepared from symptomatic Tomahawk wheat inoculated 14 days previously by a given isolate. Following inoculation, the plants

Table 1. Number of symptomatic wheat plants of different lines from different locations in Kansas infected in 2007 by different viruses or an unknown pathogen when analyzed by enzyme-linked immunosorbent assay (ELISA) against antiserum raised to Triticum mosaic virus (TriMV), Wheat streak mosaic virus (WSMV), or the High Plains virus (HPV)

\begin{tabular}{|c|c|c|c|c|c|}
\hline \multirow[b]{2}{*}{ Wheat ${ }^{y}$} & \multicolumn{4}{|c|}{ Virus, viruses, or unknown pathogens ${ }^{x}$} & \multirow[b]{2}{*}{ Total $^{\mathrm{z}}$} \\
\hline & TriMV & WSMV & TriMV/WSMV & Unknown & \\
\hline \multicolumn{6}{|l|}{ Ellis County } \\
\hline Danby & 0 & 1 & 1 & 0 & 2 \\
\hline KS970274-14-9 & 3 & 8 & 0 & 2 & 13 \\
\hline Everest & 0 & 12 & 4 & 3 & 19 \\
\hline RonL & 1 & 0 & 0 & 0 & 1 \\
\hline KS96HW10-3 & 0 & 0 & 0 & 0 & 0 \\
\hline Total percent & 11 & 60 & 14 & 14 & $\ldots$ \\
\hline \multicolumn{6}{|l|}{ Graham County } \\
\hline Danby & 0 & 1 & 1 & 3 & 5 \\
\hline KS970274-14-9 & 2 & 5 & 1 & 0 & 8 \\
\hline Everest & 1 & 6 & 2 & 2 & 11 \\
\hline RonL & 1 & 0 & 0 & 0 & 1 \\
\hline KS96HW10-3 & 0 & 0 & 0 & 0 & 0 \\
\hline Total percent & 16 & 48 & 16 & 20 & $\ldots$ \\
\hline \multicolumn{6}{|l|}{ Ness County } \\
\hline Danby & 2 & 0 & 0 & 0 & 2 \\
\hline KS970274-14-9 & 3 & 7 & 2 & 0 & 12 \\
\hline Everest & 2 & 14 & 2 & 2 & 20 \\
\hline RonL & 5 & 0 & 0 & 0 & 5 \\
\hline KS96HW10-3 & 0 & 0 & 0 & 0 & 0 \\
\hline Total percent & 31 & 54 & 10 & 5 & $\ldots$ \\
\hline
\end{tabular}

${ }^{\mathrm{x}}$ Number of plants with mosaic symptoms (e.g., $0=$ no symptomatic plants were infected with a given virus isolate or isolates or $12=12$ symptomatic plants infected with a given virus or viruses). There were approximately 36 plants $/ \mathrm{m}$ in the rows and $24 \mathrm{~m}$ of row space available for sampling of symptomatic plants for each wheat source. Range of ELISA values, for infected plants by antiserum, was TriMV, 0.092 to 0.314 , with a mean of 0.212 , and WSMV, 0.095 to 1.144 , with a mean of 0.459 ; for healthy wheat, the range by antiserum was TriMV, 0.019 to 0.030 and WSMV, 0.021 to 0.038 . Values for positive controls: TriMV $=0.306, \mathrm{WSMV}=1.144$, and HPV $=0.465$. HPV was not detected in any samples. Unknown $=$ plants with virus-like symptoms whose extracts did not react with antibodies of TriMV, WSMV, and HPV when analyzed by ELISA.

y Ellis County location of the Kansas Intrastate Wheat Nursery (KIN) was sampled 20 April 2007, Graham County KIN was sampled 20 April 2007, and Ness County KIN was sampled 24 April 2007. Total percent infection of all wheat sources was calculated by dividing the number of wheat plants infected with a given virus, viruses, or unknown pathogens with the total number of plants sampled. Total number of symptomatic plants sampled at the Ellis, Graham, and Ness locations was 35, 25 and 39, respectively.

$\mathrm{z}$ Total $=$ total number of observations for each wheat line or cultivar. 
were held at $18^{\circ} \mathrm{C}$ in a chamber and the number of symptomatic plants recorded at 7, 14, 21, and 28 DPI.

Yield effects of wheat infected with TriMV. The yield trials in the field at Colby, KS compared Danby, RonL, Jagalene, and KS96HW10-3 wheat. RonL is derived from CO960293 wheat. Both CO960293 and KS96HW10-3 have temperature-sensitive resistance to WSMV (15). Danby and Jagalene have varying levels of susceptibility to infection with WSMV. A randomized complete block experimental design was used, with each treatment replicated four times. Plots (healthy and infected for each cultivar) consisted of three rows, $2.9 \mathrm{~m}$ long with $0.3-\mathrm{m}$ row spacing, seeded at 50 $\mathrm{kg} / \mathrm{ha}$. Planting was done on 18 September 2006, the plants were mechanically inoculated at the two- to three-leaf stage with the 06123 isolate of TriMV on 16 October 2006, and harvest occurred on 28 June 2007. In 2008, the planting occurred on 19 September, inoculation with the 06-123 isolate of TriMV at the two- to threeleaf stage was done on 10 October 2008, and harvest occurred on 8 July 2009. Field inoculation was done by the air-blast inoculation technique (6). The analysis of variance was conducted using SAS (version 8; SAS Institute, Cary, NC) and significant treatment effects were determined using the least significant difference test at $P=0.05$.

\section{Results}

2007 KIN. TriMV singly infected all wheat lines except KS96HW10-3 over the three locations but not each line at each location (Table 1). WSMV did not infect RonL and KS96HW10-3 but infected all other wheat sources, except Danby at the Ness location. RonL and KS96HW10-3 wheat were not doubly infected with TriMV and WSMV while the other lines were, although not at all locations. Infection with HPV was not detected in any of the samples at any location. Symptomatic wheat plants (unknowns) whose extracts did not react with antibodies of TriMV, WSMV, or HPV in ELISA occurred in Danby, Everest, and KS970274-14-9 wheat but not at all locations. KS96HW10-3 was symptomless at all three locations.

2008 KIN. Numbers of symptomatic plants varied greatly among locations during 2008 (Table 2). TriMV and WSMV each singly infected all wheat lines except KS96HW10-3 but not at each location. Double infection of wheat with TriMV and WSMV occurred in all wheat lines except KS03HW12-6 and KS96HW10-3 but not at each location. Infection with HPV was detected twice in Hatcher wheat, and a double infection with HPV and WSMV occurred once in KS03HW12-6 wheat. Plants considered to be infected with unknown pathogens occurred in Danby, Hatcher, KS05HW15-2, and KS96HW10-3 wheat but not at each location.

2009 KIN. During 2009, wheat plants with mosaic symptoms were infected with TriMV, WSMV, and HPV (Table 3). Only the wheat cv. Everest was singly infected with TriMV, and only at the Ness County location. In addition, the only wheat sample (Danby) infected by both TriMV and WSMV occurred at this location as well. At all locations, WSMV was the predominant virus infecting the wheat lines. Interestingly, both RonL and KS96HW10-3 which have temperature-sensitive resistance to WSMV, had some plants whose extracts had antigens that reacted with WSMV antibodies in ELISA. This occurred at all locations for RonL and at the Ness location for KS96HW10-3. Different wheat sources (depending on location) had symptomatic plants whose extracts did not react to antibodies of TriMV, WSMV, or HPV and were considered as infected with unknown pathogens. Two plants had antigens that reacted to HPV antibodies and this occurred in 'Hatcher' and 'KS96HW10-3' at the Graham and Ness locations, respectively.

Table 2. Number of symptomatic wheat plants of different lines from different locations in Kansas infected in 2008 by different viruses or an unknown pathogen when analyzed by enzyme-linked immunosorbent assay (ELISA) against antiserum raised to Triticum mosaic virus (TriMV), Wheat streak mosaic virus (WSMV), or the High Plains virus (HPV)

\begin{tabular}{|c|c|c|c|c|c|c|c|}
\hline \multirow[b]{2}{*}{ Wheat $^{\mathrm{z}}$} & \multicolumn{6}{|c|}{ Virus, viruses, or unknown pathogen } & \multirow[b]{2}{*}{$N$} \\
\hline & TriMV & WSMV & TriMV/WSMV & HPV & HPV/WSMV & Unknown & \\
\hline \multicolumn{8}{|l|}{ Ellis County } \\
\hline Danby & 5 & 7 & 2 & 0 & 0 & 0 & 14 \\
\hline Hatcher & 0 & 24 & 1 & 2 & 0 & 0 & 27 \\
\hline KS03HW12-6 & 6 & 2 & 0 & 0 & 0 & 0 & 8 \\
\hline Everest & 6 & 50 & 2 & 0 & 0 & 0 & 58 \\
\hline KS05HW15-2 & 4 & 38 & 1 & 0 & 0 & 1 & 44 \\
\hline KS96HW10-3 & 0 & 0 & 0 & 0 & 0 & 1 & 1 \\
\hline Total percent & 14 & 80 & 4 & 1 & 0 & 1 & $\ldots$ \\
\hline \multicolumn{8}{|l|}{ Graham County } \\
\hline Danby & 0 & 0 & 0 & 0 & 0 & 1 & 1 \\
\hline Hatcher & 0 & 5 & 0 & 0 & 0 & 0 & 5 \\
\hline KS03HW12-6 & 0 & 1 & 0 & 0 & 0 & 0 & 1 \\
\hline Everest & 0 & 7 & 0 & 0 & 0 & 0 & 7 \\
\hline KS05HW15-2 & 0 & 2 & 0 & 0 & 0 & 0 & 2 \\
\hline KS96HW10-3 & 0 & 0 & 0 & 0 & 0 & 1 & 1 \\
\hline Total percent & 0 & 88 & 0 & 0 & 0 & 12 & $\ldots$ \\
\hline \multicolumn{8}{|l|}{ Ness County } \\
\hline Danby & 0 & 14 & 2 & 0 & 0 & 1 & 17 \\
\hline Hatcher & 1 & 32 & 3 & 0 & 0 & 2 & 38 \\
\hline KS03HW12-6 & 2 & 29 & 0 & 0 & 1 & 0 & 32 \\
\hline Everest & 2 & 99 & 3 & 0 & 0 & 0 & 104 \\
\hline KS05HW15-2 & 1 & 40 & 1 & 0 & 0 & 1 & 43 \\
\hline KS96HW10-3 & 0 & 0 & 0 & 0 & 0 & 1 & 1 \\
\hline Total percent & 3 & 91 & 4 & 0 & 0 & 2 & $\ldots$ \\
\hline
\end{tabular}

${ }^{y}$ Number of plants with mosaic symptoms (e.g., $0=$ no symptomatic plants were infected with a given virus isolate or isolates or $50=50$ symptomatic plants infected with a given virus or viruses). There were approximately 36 plants $/ \mathrm{m}$ in the rows and $24 \mathrm{~m}$ of row space available for sampling of symptomatic plants for each wheat source. Range of ELISA values for infected plants by antiserum was TriMV, 0.088 to 0.295 , with a mean of 0.169 ; WSMV, 0.111 to 0.337 , with a mean of 0.214 ; and HPV, 0.063 to 0.167 , with a mean of 0.115 ; and, for healthy wheat, the range by antiserum was TriMV, 0.016 to 0.026 ; WSMV, 0.027 to 0.036 ; and HPV, 0.011 to 0.20 . Values for positive controls were TriMV $=0.254$, WSMV $=0.508$, and HPV $=0.241$. Unknown $=$ plants whose extracts did not react with antibodies of TriMV, WSMV, and HPV when analyzed by ELISA. $N=$ number of observations for each wheat line or cultivar.

${ }^{z}$ Ellis County, KS location of the Kansas Intrastate Wheat nursery (KIN) was sampled 22 April 2008, Graham County KIN was sampled 24 April 2008 , and Ness County KIN was sampled 23 April 2008. The total percent infection of all wheat sources with was calculated by dividing the number of wheat plants infected with a given virus, viruses, or unknown pathogens with the total number of plants sampled. Total number of symptomatic plants sampled at the Ellis, Graham, and Ness locations was 152, 17, and 235, respectively. 
When taken across cultivars at all locations by year of sampling, there was a trend for the infection of wheat by TriMV to decline during the 3 years (Table 4). The average infection with TriMV was $19.0 \%$ in 2007 and declined to $1.0 \%$ in 2009 . A decrease from 14.0 to $1.0 \%$ was observed for wheat infected by both TriMV and WSMV. During this time, there was a trend for plants infected with only WSMV to increase from 54.0 to $90.0 \%$.

At the 32-ha field in Ness County sampled in 2009, 36 of 40 plants sampled were infected by both TriMV and WSMV (Table 5). Four plants were infected with only WSMV. No HPV was detected.

WSMV isolates from lines with temperature-sensitive resistance to WSMV. The five WSMV isolates obtained from KS96HW10-3 or RonL did not infect any wheat line with the temperature-sensitive WSMV resistance when mechanically inoculated with these isolates held at $18^{\circ} \mathrm{C}$. However, the Tomahawk wheat control plants inoculated with a given isolate all displayed systemic mosaic symptoms by 14 DPI when held at $18^{\circ} \mathrm{C}$ (data not shown).

Yield components. The average percent infection in 2007 of the TriMV-inoculated plots of KS96HW10-3 wheat was 0 and, for Danby, RonL, and Jagalene, each was estimated at 95\%. During 2007, the yield of the treatments inoculated with TriMV was significantly lower than for their healthy counterparts, except for KS96HW10-3 (Table 6). The same results were observed for the volume weight measurements for each wheat source. In 2009, the average percent infection of the inoculated plots of KS96HW10-3 was 0 and, for Danby, RonL, and Jagalene, it was estimated at 97, 84 , and $96 \%$, respectively. Again in 2009, the yield of the inoculated treatments for each cultivar was significantly lower than the healthy controls, except for KS96HW10-3. The same results were observed for the volume weight in 2009 for each cultivar. Infection of plants in the healthy control plots was not observed in either year.

\section{Discussion}

Variation in levels of infection for TriMV, WSMV, and HPV among wheat lines at the different locations and among sampling years for the locations was observed. This variability is probably influenced by the proximity of wheat or grassy weeds infected by TriMV, WSMV, or HPV and the numbers of WCM infesting the wheat because these viruses are all transmitted by the WCM $(9,11,18)$. In previous studies with TriMV (11) and HPV (9), the percent infection of wheat decreased with distance from the WCM source. The lack of infection of RonL and KS96HW10-3 with WSMV relates to the WSMV temperature-sensitive resistance associated with these lines $(13,15)$. At these locations, our results showed that infection of wheat by WSMV occurred most frequently, followed by plants infected with either TriMV or both TriMV and WSMV depending on year and location, and then HPV. Burrows (1) showed that $47 \%$ of samples taken from different states in the Great Plains were infected with WSMV, followed by 19\% with HPV and $17 \%$ with TriMV.

Table 3. Number of symptomatic wheat plants of different lines from different locations in Kansas infected in 2009 by different viruses or an unknown pathogen when analyzed by enzyme-linked immunosorbent assay (ELISA) against antiserum raised to Triticum mosaic virus (TriMV), Wheat streak mosaic virus (WSMV), or the High Plains virus (HPV)

\begin{tabular}{|c|c|c|c|c|c|c|c|}
\hline \multirow[b]{2}{*}{ Wheat $^{y}$} & \multicolumn{5}{|c|}{ Virus, viruses, or unknown pathogens } & \multirow[b]{2}{*}{ Unknown } & \multirow[b]{2}{*}{$N^{\mathrm{z}}$} \\
\hline & TriMV & WSMV & TriMV/WSMV & HPV & HPV/WSMV & & \\
\hline \multicolumn{8}{|l|}{ Ellis County } \\
\hline Danby & 0 & 3 & 0 & 0 & 0 & 0 & 3 \\
\hline Hatcher & 0 & 4 & 0 & 0 & 0 & 0 & 4 \\
\hline Everest & 0 & 11 & 0 & 0 & 0 & 0 & 11 \\
\hline RonL & 0 & 1 & 0 & 0 & 0 & 1 & 2 \\
\hline KS96HW10-3 & 0 & 0 & 0 & 0 & 0 & 0 & 0 \\
\hline Total percent & 0 & 95 & 0 & 0 & 0 & 5 & $\ldots$ \\
\hline \multicolumn{8}{|l|}{ Graham County } \\
\hline Danby & 0 & 8 & 0 & 0 & 2 & 0 & 10 \\
\hline Hatcher & 0 & 11 & 0 & 1 & 0 & 2 & 14 \\
\hline Everest & 0 & 15 & 0 & 0 & 0 & 0 & 15 \\
\hline RonL & 0 & 8 & 0 & 0 & 0 & 0 & 8 \\
\hline KS96HW10-3 & 0 & 0 & 0 & 0 & 0 & 0 & 0 \\
\hline Total percent & 0 & 90 & 0 & 2 & 4 & 4 & $\ldots$ \\
\hline \multicolumn{8}{|l|}{ Ness County } \\
\hline Danby & 0 & 3 & 1 & 0 & 0 & 0 & 4 \\
\hline Hatcher & 0 & 7 & 0 & 0 & 0 & 1 & 8 \\
\hline Everest & 1 & 14 & 0 & 0 & 0 & 1 & 16 \\
\hline RonL & 0 & 1 & 0 & 0 & 0 & 0 & 1 \\
\hline KS96HW10-3 & 0 & 4 & 0 & 1 & 0 & 0 & 5 \\
\hline Total percent & 3 & 85 & 3 & 3 & 0 & 6 & $\ldots$ \\
\hline
\end{tabular}

${ }^{y}$ Ellis County location of the Kansas Intrastate wheat Nursery (KIN) was sampled April 20 2009, the Graham County KIN was sampled 7 May 2009 , and the Ness County KIN was sampled 4 May 2009. Total percent infection of all wheat sources with was calculated by dividing the number of wheat plants infected with a given virus, viruses, or unknown pathogens with the total number of plants sampled. Total number of symptomatic plants sampled at the Ellis, Graham, and Ness locations was 20, 47, and 34, respectively.

${ }^{\mathrm{z}} N=$ number of observations for each wheat line or cultivar.

Table 4. Percent infection across wheat cultivars or lines at three locations in Kansas for Triticum mosaic virus (TriMV), Wheat streak mosaic virus (WSMV), the High Plains virus (HPV), combinations of these viruses, and unknown pathogens

\begin{tabular}{lcccccc}
\hline & \multicolumn{5}{c}{ Viruses or unknown pathogen } \\
\cline { 2 - 6 } Year $^{\mathbf{z}}$ & TriMV & WSMV & TriMV/WSMV & HPV & HPV/WSMV & Unknown \\
\hline 2007 & 19 & 54 & 14 & 0 & 0 & 1 \\
2008 & 6 & 86 & 3 & 0 & 1 & 5 \\
2009 & 1 & 90 & 1 & 2 & 5 & 1 \\
\hline
\end{tabular}

${ }^{y}$ Unknown describes plants with virus-like symptoms whose extracts did not react with antibodies of TriMV, WSMV, and HPV when analyzed by enzymelinked immunosorbent assay.

z Total number of wheat samples was 99, 404, and 101 for 2007, 2008, and 2009, respectively. 
RonL wheat has temperature-sensitive resistance to WSMV and KS96HW10-3 is the only wheat line currently identified with temperature-sensitive resistance to both WSMV and TriMV (4). It was interesting to find that four KS96HW10-3 plants and one RonL plant from the 2009 Ness County KIN were infected with WSMV (Table 4). One reason for this may have been the emergence of a WSMV isolate or isolates that could defeat the WSMV resistance in KS96HW10-3 and RonL. However, the four WSMV isolates obtained from KS96HW10-3 and the single isolate from RonL did not infect RonL or KS96HW10-3 when these lines were held at $18^{\circ} \mathrm{C}$ following mechanical inoculation with the WSMV isolates. Therefore, the infection of these two wheat sources in the field may have been the result of a few off-type plants present in these lines or temperature conditions that were conducive to infection when they were infested with WCM viruliferous for WSMV in the field.

Our results during 2007 to 2009 are in contrast to those we observed at a single location growing next to volunteer wheat with a high level of double infection with TriMV and WSMV and plants that were heavily infested with WCM (11). In that study, 100 wheat plants growing immediately next to the volunteer wheat were analyzed at different distances from the volunteer wheat: $67 \%$ were doubly infected with TriMV and WSMV, 22\% infected with WSMV only, and $11 \%$ infected with TriMV only. Again, this probably reflects the distance from the source of the WCM vector and high numbers of WCM that were present at that location. Also, in the current study, the 32-ha field in the Ness County KIN had $85 \%$ of the symptomatic plants infected with both TriMV and WSMV, which contrasted with the $3.0 \%$ observed the same day 1.6 km away at the Ness County KIN.

At the KIN locations, there was a trend for a decline in plants infected with TriMV and an increase in plants infected with WSMV from 2007 to 2009 (Table 4). One might expect that this would not have been observed because of the numbers of samples taken during these 3 years. In 2007, 99 samples were taken, followed by a

Table 5. Numbers of wheat plants infected with Triticum mosaic virus (TriMV), Wheat streak mosaic virus (WSMV), or both viruses from a field in Ness County, KS in 2009

\begin{tabular}{lccc}
\hline & & \multicolumn{2}{c}{ Antiserum $^{\mathbf{x}}$} \\
\cline { 3 - 4 } Virus and controls & Infected/sampled $^{\mathbf{y}}$ & \multicolumn{1}{c}{ TriMV } & WSMV \\
\hline TriMV & $0 / 40$ & NA $^{\mathrm{z}}$ & $\mathrm{NA}$ \\
WSMV & $4 / 40$ & $\mathrm{NA}$ & $0.387-0.725$ \\
TriMV and WSMV & $36 / 40$ & $0.079-0.610$ & $0.387-1.183$ \\
TriMV control & $\mathrm{NA}$ & 0.634 & 0.036 \\
WSMV control & $\mathrm{NA}$ & 0.030 & 0.792 \\
Healthy wheat & $\mathrm{NA}$ & 0.030 & 0.044 \\
\hline
\end{tabular}

${ }^{x}$ Range of enzyme-linked immunosorbent assay values.

${ }^{y}$ Number of infected/sampled plants. The 32-ha field in Ness County, KS was a mixture of TAM 112 and T136 wheat plants and was $1.6 \mathrm{~km}$ from the Ness Kansas Intrastate Nursery site and sampled on 4 May 2009, the same day as the Ness location in Table 3.

${ }^{\mathrm{z}} \mathrm{NA}=$ not applicable peak of 404 in 2008 and 101 in 2009. Thus, with four times as many samples in 2008, the same decline in or increase in numbers of plants infected with a respective virus occurred. This seems to indicate that TriMV levels were decreasing in the areas sampled. However, our sampling of a field $1.6 \mathrm{~km}$ from the Ness County KIN location on the same day as the KIN was sampled showed that 40 random symptomatic wheat samples had 36 of 40 plants $(85 \%)$ infected with TriMV and WSMV (Table 5). We cannot ascertain the source of WCM that infested the wheat plants at the KIN Ness County location. However, if the WCM infesting the wheat plants at the Ness County KIN site were representative of those causing infection of the plants at the 32-ha field $1.6 \mathrm{~km}$ away, then high numbers of plants infected with TriMV or TriMV and WSMV would be expected. However, this was not observed. It is possible that the 32-ha field was infested early in the fall and an increase of WCM to sufficient numbers did not occur until the following spring, so that few WCM from this location actually were available to infest wheat plants at the KIN location. It is also possible that the $1.6-\mathrm{km}$ distance between the two locations prevented infestation of the KIN wheat from this location. If so, then the WCM infesting the Ness KIN wheat plants may have been from a different location and may have differed in their capacity to transmit TriMV. In another study, WCM from different geographic regions differed in their capacity to transmit HPV (8). Clearly, there is deficiency in the information concerning environmental effects on acquisition of TriMV by WCM and the interaction of WCM from different geographic sources using different TriMV sources. If different sources of WCM can transmit TriMV at different levels, then results of studies at different geographic locations might not be predictive of results for other locations.

Symptoms were not observed in plants of KS96HW10-3 inoculated with TriMV in the field yield plots but were observed in the inoculated plants of the other wheat sources during the spring following the fall inoculation. This symptom expression pattern correlates well with the lack of significant difference in yield of the KS96HW10-3-inoculated plants compared with the healthy counterpart. Inoculated plants of the other wheat lines had symptoms and significant reductions in yield compared with their respective controls. These responses occurred in both the 2007 and 2009 trials. The results with KS96HW10-3 are not unexpected because it has been shown to have temperature-sensitive resistance to infection with TriMV in growth chamber studies that is effective at 18 but not at $24^{\circ} \mathrm{C}$, where systemic infection of plants occurs (4). RonL and KS96HW10-3 both have effective levels of resistance to WSMV when tested under WSMV pressure in the field $(14,15)$, whereas Danby and Jagalene are susceptible to infection by WSMV (D. Seifers, unpublished).

Our results demonstrate that infection of wheat with TriMV varies greatly with location and that infection of wheat with TriMV only was lower than for WSMV only. However, the levels of infection of wheat by both TriMV and WSMV were high depending upon sampling location and year. Infection with TriMV caused significant reduction in yields of Danby, RonL, and Jagalene wheat

Table 6. Grain yield and volume weight of wheat cultivars either healthy or infected by Triticum mosaic virus in 2007 and 2009 at Colby, KS

\begin{tabular}{|c|c|c|c|c|c|}
\hline \multirow[b]{2}{*}{ Cultivar } & \multirow[b]{2}{*}{ Treatment } & \multicolumn{2}{|c|}{ Yield (kg/ha) } & \multicolumn{2}{|c|}{ Volume weight $\left(\mathrm{kg} / \mathrm{m}^{3}\right)$} \\
\hline & & 2007 & 2009 & 2007 & 2009 \\
\hline Danby & Healthy & $5,146 \mathrm{~A}$ & $4,073 \mathrm{AB}$ & $808 \mathrm{~A}$ & $768 \mathrm{~A}$ \\
\hline Danby & Infected & $3,984 \mathrm{C}$ & $3,108 \mathrm{C}$ & $796 \mathrm{~B}$ & $730 \mathrm{BC}$ \\
\hline RonL & Healthy & $4,911 \mathrm{~A}$ & $4,394 \mathrm{~A}$ & $805 \mathrm{~A}$ & $764 \mathrm{~A}$ \\
\hline RonL & Infected & $2,203 \mathrm{E}$ & $1,058 \mathrm{D}$ & $783 \mathrm{C}$ & $580 \mathrm{E}$ \\
\hline Jagalene & Healthy & $4,461 \mathrm{~B}$ & $3,805 \mathrm{~B}$ & $812 \mathrm{~A}$ & $729 \mathrm{C}$ \\
\hline Jagalene & Infected & $3,682 \mathrm{D}$ & $2,920 \mathrm{C}$ & $782 \mathrm{C}$ & $707 \mathrm{D}$ \\
\hline KS96HW10-3 & Healthy & $4,333 \mathrm{~B}$ & $4,030 \mathrm{AB}$ & $809 \mathrm{~A}$ & $746 \mathrm{~B}$ \\
\hline KS96HW10-3 & Infected & $4,286 \mathrm{~B}$ & 3,947 B & $810 \mathrm{~A}$ & 743 BC \\
\hline $\mathrm{CV}^{\mathrm{z}}$ & $\ldots$ & 4.1 & 7.3 & 0.5 & 1.5 \\
\hline
\end{tabular}

y Treatments not having the same letter in common within a column are significantly different using the least significance difference test $(P=0.05)$.

${ }^{\mathrm{z}}$ Coefficient of variation. 
but not KS96HW10-3 that has temperature-sensitive resistance to both TriMV and WSMV.

\section{Acknowledgments}

We thank J. Ackerman for his valuable assistance in ELISA analyses and greenhouse studies and C. Seaman for assistance with the field planting and sampling of wheat used for ELISA analyses.

\section{Literature Cited}

1. Burrows, M., Franc, G., Rush, C., Blunt, T., Ito, D., Kinzer, K., Olson, J., O'Mara, J., Price, J., Tande, C., Ziems, A., and Stack, J. 2009. Occurrence of viruses in wheat in the Great Plains Region, 2008. Online. Plant Health Progress doi:10.1094/PHP-2009-0706-01-RS.

2. Burrows, M., and Stack, J. 2009. Great Plains diagnostic network regional wheat virus survey: collaboration, communication, research and extension outcomes. Poster at NPDN National Meeting, Miami, FL.

3. Fellers, J. P., Seifers, D., Ryba-White, M., and Martin, T. J. 2009. The complete sequence of Triticum mosaic virus, a new wheat infecting virus of the Great Plains. Arch. Virol. 154:1511-1515.

4. Friebe, B., Qi, L. L., Wilson, D. L., Chang, Z. J., Seifers, D. L., Martin, T. J., Fritiz, A. K., and Gill, B. S. 2009. Wheat-Thinopyrum intermedium recombinants resistant to Wheat streak mosaic virus and Triticum mosaic virus. Crop Sci. 49:1221-1226.

5. Louie, R., Seifers, D. L., and Bradfute, O. E. 2006. Isolation, transmission and purification of the High Plains virus. J. Virol. Methods 135:214-222.

6. Martin, T. J., and Hackerott, H. L. 1982. Greenhouse seedling technique to determine the reaction of sorghum to maize dwarf mosaic virus strain A. Crop Sci. 22:1255-1256.

7. Seifers, D. L. 1992. Partial characterization of a Colorado isolate of Agropyron mosaic virus. Plant Dis. 76:564-569.

8. Seifers, D. L., Harvey, T. L., Louie, R., Gordon, D. T., and Martin, T. J. 2002. Differential transmission of isolates of the High Plains virus by different sources of wheat curl mites. Plant Dis. 86:138-142.

9. Seifers, D. L., Harvey, T. L., Martin, T. J., and Jensen, S. G. 1997. Identification of the wheat curl mite as the vector of the High Plains virus of corn and wheat. Plant Dis. 81:1161-1166.

10. Seifers, D. L., and Martin, T. J. 2009. Differential hosts for Triticum mosaic virus and Wheat streak mosaic virus. (Abstr.) Phytopathology 99:S117.

11. Seifers D. L., Martin T. J., Harvey T. J., Fellers J. P., and Michaud J. P. 2009. Identification of the wheat curl mite as the vector of Triticum mosaic virus. Plant Dis. 93:25-29.

12. Seifers, D. L., Martin, T. J., Harvey, T. L., Fellers, J. P., Stack, J. P., RybaWhite, M., Haber S., Krokhin, O., Spicer, V., Lovat, N., Yamchuk, A., and Standing, K. G. 2008. Triticum mosaic virus: a new virus isolated from wheat in Kansas. Plant Dis. 92:808-817.

13. Seifers, D. L., Martin, T. J., Harvey, T. L., and Gill, B. S. 1995. Temperature sensitivity and efficacy of wheat streak mosaic virus resistance derived from Agropyron intermedium. Plant Dis. 79:1104-1106.

14. Seifers, D. L., Martin, T. J., Harvey, T. L., and Haber, S. 2007. Temperaturesensitive Wheat streak mosaic virus resistance identified in KS03HW-12 wheat. Plant Dis. 91:1029-1033.

15. Seifers, D. L., Martin, T. J., Harvey, T. L., Haber, S., and Haley, S. D. 2006 Temperature sensitivity and efficacy of Wheat streak mosaic virus resistance derived from C0960293 wheat. Plant Dis. 90:623-628.

16. Seifers, D. L., Martin, T. J., Harvey, T. L., Haber, S., Krokhin, O., Spicer, V., Ying, S., and Standing, K. G. 2009. Identification of variants of the High Plains virus infecting wheat in Kansas. Plant Dis. 93:1265-1274.

17. Skare, J. M., Wijkamp, I., Dehnam, I., Rezende, J. A. M., Kitajima, E. W., Park, J.-W., Benedicte, D., Rush, C. M., Michels, G., Scholthof, K. B. G., and Scholthof, H. B. 2006. A new eriophyid mite-borne membrane-enveloped virus-like complex isolated from plants. Virology 347:343-353.

18. Slykhuis, J. T. 1955. Aceria tulipae Keifer (Acrina: Eriophyidae) in relation to the spread of wheat streak mosaic. Phytopathology 45:116-128.

19. Tatineni, S., Graybosch, R. A., Hein, G. L., Wegulo, S. N., and French, R. 2010. Wheat cultivar-specific synergism and alteration of virus accumulation during co-infection with Wheat streak mosaic virus and Triticum mosaic virus. Phytopathology 100:230-238.

20. Tatineni, S., Ziems, A. D., Wegulo, S. N., and French, R. 2009. Triticum mosaic virus: a distinct member of the family Potyviridae with an unusually long leader sequence. Phytopathology 99:943-950. 